\title{
Academic Dishonesty, Plagiarism Included, in the Digital Age: A Literature Review
}

\section{Zorana Ercegovac and John V. Richardson Jr.}

\begin{abstract}
The reviewed literature reported on plagiarism in the context of the digital era from the perspective of a broader educational spectrum. The authors of this review ask questions with regard to what constitutes plagiarism, how prevalent plagiarism is in our schools, colleges, and society, what is done to prevent and reduce plagiarism, the attitudes of faculty toward academic dishonesty in general, and individual differences as predictors of academic dishonesty. This article identifies research questions that have not been addressed sufficiently in the literature and suggests specific research areas for further investigation.
\end{abstract}

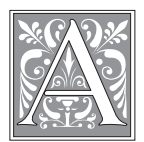

t the outset of this search, the literature on plagiarism seemed well defined and sufficiently narrow in scope. However, as the authors went deeper into the topic, they discovered that this was hardly the case. The problem may be attributed, in part, to the interdisciplinary nature of the topic and the ethical challenges of accessing and using information technology, especially in the age of the Internet. Writings have been reported in the literatures of education, psychology, and library and information studies, each looking at academic dishonesty from different perspectives. The literature has been aimed at instructors and scholars in education and developmental psychology, as well as college librarians and school media specialists. Some writings have come from software houses that provide detection services; there were plenty of advertisements from paper mills announcing thousands of canned reports to students. However, the authors saw no attempts to connect these seemingly disparate bodies of literature. For example, seminal writings by John Dewey, Jean Piaget, and Lawrence Kohlberg could provide a solid theoretical framework in moral reasoning and a good starting point to build on. ${ }^{1-5}$ Their work should be considered by

Zorana Ercegovac is a Researcher in the Henry Samueli School of Engineering and Applied Sciences at the University of California, Los Angeles (UCLA), and the Director of Library, Information Studies and Archives, in the Windward School, Los Angeles. John V. Richardson Jr. is a Professor in the Graduate School of Education and Information Studies and Associate Dean in the Graduate Division at UCLA. Correspondence concerning this article should be addressed to Zorana Ercegovac at zercegov@ucla.edu. Dr. Ercegovac wishes to thank Tom Gilder, Head of Windward School, for supporting, in part, this project. Special thanks go to Dr. David Unger, the Director of Counseling Services for Windward Upper School, who pointed out the importance of Kohlberg's work for our understanding of moral reasoning of adolescent learners. 
education and library communities in any efforts to design well-grounded academic honesty policies and programs for learners across the educational spectrum.

Although the literature appears to be scattered across many fields, standard dictionaries and encyclopedias agree on the meaning of plagiarism. The authors consulted Webster's College Dictionary, Oxford English Dictionary, West's Encyclopedia of the American Law, and The Internet Encyclopedia of Philosophy. ${ }^{6-9}$ According to Webster's, plagiarism is equated with kidnapping and defined as "the unauthorized use of the language and thoughts of another author and the representation of them as one's own." 10 The Oxford English Dictionary defines plagiarism as the "wrongful appropriation or purloining, and publication as one's own, of the ideas, or the expression of the ideas (literary, artistic, musical, mechanical, etc.)."11 OED cites numerous sources that mention plagiarism in different historical contexts, starting with a citation from 1621.

These two dimensions, literature on moral judgment and the general definitional agreement of what is meant by plagiarism, provided the main structure for this literature review.

\section{The Approach}

After discussing motivation and specifications for this search, this review examines several literatures for effective pedagogical approaches instructors can use to design academic integrity programs, in particular, plagiarism, that would be appropriate for secondary and college-level students. Students reason differently when presented with specific moral dilemmas. ${ }^{12,13}$ According to The Internet Encyclopedia of Philosophy, a moral dilemma "involves a situation in which the agent has only two courses of action available, and each requires performing a morally impermissible action."14 This moral dilemma also has been brought to the attention of one of the authors (Ercegovac) in her own classroom experience with different populations of learnerssecondary school students and college students (1991 to present). It is simply not enough to define plagiarism, distribute neatly prepared citation templates for different formats, and say that plagiarism is wrong, punishable, easily detectable, and against honor codes, especially when applied generically across the board.

Instead, the authors conjectured that if knowledge about distinct phases of moral capacities among children, adolescents, and college students were used, they might be able to design appropriate educational programs that account for these differences among groups of learners. Units on academic integrity could be included throughout the educational cycle and across disciplinary lines (e.g., sciences, the arts). More effective pedagogical tools are needed to engage students in real-life moral dilemmas at their levels of moral reasoning.

\section{Literature Search: Terms and Databases}

Broader headings to plagiarism for the purposes of searching online databases include:

- cheating (education) or academic dishonesty or academic misconduct;

- copyright infringement;

- intellectual property;

- moral judgment (reasoning) or moral thinking;

- moral development or character building.

More specific headings to plagiarism are:

- cyberplagiarism or Internet in education;

- Internet cheating, cheating behavior (Web).

Another related topic is the concept 
of honor code. Other headings used to qualify search results relate to age groups: middle school children, high school children, secondary school children, youth, adolescents, teenagers, and college students. The intersection of the following three boxes represents the literature the authors sought to find:

\begin{tabular}{|c|c|c|c|c|}
\hline $\begin{array}{c}\text { plagiarism } \\
\text { related } \\
\text { terms }\end{array}$ & and & $\begin{array}{l}\text { Web- } \\
\text { related } \\
\text { terms }\end{array}$ & and & $\begin{array}{l}\text { age group } \\
\text { related } \\
\text { terms }\end{array}$ \\
\hline
\end{tabular}

Library of Congress Subject Headings lists the following useful headings for the field of plagiarism: The main heading "cheating" from the perspective of education may be subdivided geographically; it is Used For (UF) "academic dishonesty," "student cheating," and "student dishonesty." The heading of "plagiarism," which also may be subdivided geographically, is seen as Narrower To (NT) "authorship," "copyright infringement," "literary ethics," "literature," "quotation," and "torts." It is Related To (RT) the headings of "imitation in literature" and "originality in literature." Another main heading is "plagiarism in music." 15

Surprisingly, Sears List of Subject Headings has no headings under "plagiarism," "cheating," or "intellectual property." There are headings such as "honesty," which is Used For (UF) "dishonesty," and "moral education," which is UF "character education" and "ethical education." 16

These two cataloging sources are used to describe publications in academic and school libraries as well as public libraries. Although the two sets of subject headings differ in their treatment of headings that are to be used to describe contents of publications on various forms of cheating, the authors found an equal number of writings on these topics for both college and secondary school readers.
The authors searched Education Index and Library Literature Index, ProQuest, and OCLC's FirstSearch databases on December 7, 2002, and again in April and May of 2003. Finally, a search of the online library catalog Orion2® at UCLA retrieved several monographs within the authors' specification. Because the interest has been in the body of literature on plagiarism in the Web environment, or cyber-plagiarism, the search covered a five-year publication period (1997 to 2002, conveying 1996 to early 2003 papers). The retrieved items are published in journals, newspapers, reports (from ERIC database), doctoral dissertations (one by Jonathan L. Burke and another by Helene Elizabeth Marcoux), collections of articles, conference presentations, and monographs. ${ }^{17,18}$ From the initial search result of more than three hundred items at the time of this writing, one-third were selected. The authors have included publications written for instructors and librarians with a limited number of papers presented at regional conferences and reports.

Other sources include selected Web pages, including the University of California at Berkeley (http://teaching.berkeley. edu/bgd/prevent.html), the University of Wisconsin (http://www.uwplatt. edu/ library/reference/plagiarism.htmlx), Eastern Illinois University (http://www. wiu.edu/users/mfbhl/wiu/plagiarism. htm), the University of Oregon (http:// libweb.uoregon.edu/guides/plagiarism/ faculty/), the University of Alberta (http:// www.library.ualberta.ca/guides/plagiarism/preventing/index.cfm), and the University of Texas (http://www.lib.utexas. edu/services/instruction/faculty/plagia$\mathrm{rism} /$ ). A compilation of articles from a variety of sources on plagiarism-related issues is maintained by the Center for Teaching and Learning (http://www.umsl. edu/services/cte/Movies/CheatingInternet.htm). Another list is published 
in appendix F of Robert A. Harris's Plagiarism Handbook and organized under several headings, such as "honor codes," "statements on plagiarism and academic integrity by seven major universities," and "how to avoid plagiarism."19

\section{What Has the Literature Search Uncovered? \\ Definitions of Academic Dishonesty}

In addition to previously mentioned definitions of plagiarism from dictionaries and encyclopedias, William L. Kibler defined academic dishonesty as "forms of cheating and plagiarism that involve students giving or receiving unauthorized assistance in an academic exercise or receiving credit for work that is not their own." 20 Burke investigated the concept of plagiarism in his unpublished doctoral dissertation. He seemed to have agreed with Pavela on different forms of academic dishonesty. ${ }^{21}$ Both Pavela and Burke distinguish among the four forms of cheating. According to Burke, cheating is "intentionally using or attempting to use unauthorized materials, information, or study aids in any academic exercise." He defines fabrication as "intentional and unauthorized falsification or invention of any information or citation in an academic exercise." Facilitating academic dishonesty is defined as "intentionally or knowingly helping or attempting to help another to commit an act of academic dishonesty," and plagiarism is defined as "intentionally or knowingly representing the word of another as one's own in any academic exercise." 22

Numerous other writers have attempted to define the concept of plagiarism. In an excellent bibliography on plagiarism that reviews nearly seven hundred publications between 1900 and 1995, Judy Anderson discussed different definitions in the historical, chronological, cultural, and disciplinary contexts. ${ }^{23}$
Shelley Angélil-Carter also discussed the development of the notion of plagiarism, along with copyright, from the historical perspective. ${ }^{24}$ She tried to convey that plagiarism is an elusive concept and has been treated differently in different contexts. In the introduction to her book Stolen Language? Plagiarism in Writing, she wrote that she wanted to "understand plagiarism differently" and to communicate that understanding to teachers and writers of academic discourse. Laurie Stearns defined plagiarism as "intentionally taking the literary property of another without attribution and passing it off as one's own, having failed to add anything of value to the copied material and having reaped from its use an unearned benefit." ${ }^{25}$ Her definition comes from several sources, including Black's Law Dictionary, The Oxford English Dictionary, Webster's Third New International Dictionary of the English Language Unabridged, and K. R. St. Onge's work, The Melancholy Anatomy of Plagiarism. ${ }^{26}$

In one of her general education classes at Colgate University, Rebecca Moore Howard found that one-third of her students plagiarized an assigned paper. ${ }^{27}$ She characterized student plagiarism as "patchwriting," which she defined as "copying from a source text and then deleting some words, altering grammatical structures, or plugging in one synonym for another." Earl Babbie wrote that "presenting someone else's words or ideas as your own - in any form - constitutes plagiarism." He equated plagiarism with lying, stealing, and insulting. ${ }^{28}$ Patrick A. Cabe also has distinguished different types of plagiarism: direct plagiarism; truncation (where strings are deleted in the beginning or ending); excision (strings are deleted from the middle of sentences); insertions; inversions; substitutions; change of tense, person, number, or voice; undocumented factual information; in- 
appropriate use of quotation marks; or paraphrasing. ${ }^{29}$ The Council of Writing Program Administrators (CWPA) has defined plagiarism as a deliberate use of “someone else's language, ideas, or other original (not common-knowledge) material without acknowledging its source." ${ }^{30}$ This definition is extended to printed and digital materials, manuscripts, and other works. Plagiarism is interrelated to intellectual property, copyright, and authorship, and is discussed from the perspective of multiculturalism. ${ }^{31}$

Jeffrey Klausman made three distinctions among direct plagiarism, paraphrase plagiarism, and patchwork plagiarism. ${ }^{32}$ Jane Lasarenko offered exercises to help students understand the differences between summarizing and paraphrasing practices, and how both can result in plagiarism if the original sources are not cited..$^{33}$ Along this line, in 2000, Ann Lathrop and Kathleen Foss wrote a practical guide for educators and parents of secondary school students who wish to avoid these types of plagiarism. ${ }^{34}$ Harris's Plagiarism Handbook has been useful in workshops that Ercegovac developed to teach middle- and upper-school students and teachers. ${ }^{35}$ Gary J. Niels opined that "many students are ignorant of the guidelines pertaining to academic integrity and even when they do understand they often attribute differing values to their importance." ${ }^{36}$ In two separate studies with college students at St. John's University in New York, Miguel Roig asked students to determine which of ten rewritten versions were plagiarized. ${ }^{37} \mathrm{He}$ found that 40 to 50 percent of the students did not identify plagiarized versions, which, he suggested, indicated that students in his tests were unclear as to what plagiarism means.

Learners need to be introduced to appropriate academic conduct. All these different forms of academic dishonesty should be explained to students regardless of their academic status. However, we need to develop appropriate levels of presentation to different levels of students' moral reasoning. This link has not been exploited as yet in the published literature. It is an opportunity for educators and librarians to explore this challenging area together.

\section{Performance Indicators Showing Out- comes for Information Literacy Concern- ing Plagiarism in IL Standards}

With regard to different forms of academic cheating, both ACRL's Information Literacy Standards for Higher Education and ALA's Information Power: Building Partnerships for Learning give specific performance indicators for colleges and secondary schools, respectively. ${ }^{38,39}$ For example, Information Literacy Standards for Higher Education provides ample guidance on the ethical use of information in indicators $5 \mathrm{a}, 5 \mathrm{c}-5 \mathrm{~d}$ (per standard 2), indicator 1c (per standard 3), indicators $1 \mathrm{c}-1 \mathrm{~d}$ (standard 4), and indicators 3a-3b (per standard 5). Information Power offers guidance to library media specialists under the heading "Social Responsibility Standards" (specifically, indicators 2-3 in standard 8). Because both sets of standards promote the use of a wide variety of sources in student research (e.g., textual, graphical, geospatial, motion pictures, three-dimensional objects, and musical), examples in IL units need to be drawn from a variety of formats, moral scenarios, and different disciplines.

In summary, the reviewed literature has focused primarily on plagiarism issues found among college students, including community colleges. ${ }^{40-47} \mathrm{~A}$ subset of that literature is concerned with plagiarism problems among business students, engineers, scientists, and dentistry students. ${ }^{48-54}$ A substantial number of papers have dealt with ways 
to reduce plagiarism. ${ }^{55-65}$ Numerous writings were concerned with detection tools and strategies, awareness of paper mills, and general trends. ${ }^{66-72}$ Important studies were written for secondary school readers. ${ }^{73-82}$

The most important writings, however, have come from the work of Dewey, Piaget, and especially Kohlberg. Another body of literature has studied variables that are strongly associated with academic cheating. ${ }^{83-91}$

\section{Coping with Academic Dishonesty in the Age of the Internet}

\section{How Prevalent Is Academic Dishonesty on Campuses?}

The authors of this article have personally experienced classroom situations in which academic cheating, especially various forms of "cut-and-paste" plagiarism stolen off the Web, is widespread. The problem appears to be on the rise in scholarly communities, among scientific communities, and among politicians and journalists..$^{92-98}$ For example, in the chapter titled "Youth: Changing Beliefs and Behavior" in The State of Americans, it is said that 58.3 percent of high school students let someone else copy their work in 1969 and 97.5 percent did so in 1989. Moreover, the percentage of students who report ever using a cheat sheet doubled from 34 to 68 percent. ${ }^{99}$ Surprisingly, nearly 90 percent of college students "strongly agree or somewhat agree" that it is wrong to "hand in someone else's writing as one's own," to "use the Internet to copy text to hand in as one's own," and to "purchase papers from print term-paper mills." 100

Kibler reviewed literature that demonstrates that various forms of academic dishonesty have been with us since ancient civilizations and that academic dishonesty, for a variety of reasons, has increased. ${ }^{101}$ In his Plagiarism Handbook,
Harris noted that a "free-term-paper site, run by a 16-year-old, receives 13,000 hits a day." ${ }^{102}$ Harris gave an example of a librarian who studied plagiarism herself and could not order a paper from a paper mill because the site was "flooded with 800 orders a day." ${ }^{103}$ His book marshals lively instructional cartoons that could be used in teaching and discussing the subject of plagiarism. Edward Humes provided anecdotes from his own observations and interviews with students, administrators, and parents at an academically outstanding high school in Cerritos, California. ${ }^{104}$

Niels cited a massive study of high achievers conducted by Who's Who among High School Students in 1993 that found that "nearly $80 \%$ admitted to some form of dishonesty, such as copying someone else's homework or cheating on an exam." He also found that "of the private school students, nearly $60 \%$ indicated that in their schools cheating is either 'fairly common' or 'everybody does it.'"'105

Roberts, Anderson, and Yanish found that in the self-reported surveys of 422 college students at a mid-sized four-year public university, 91.7 percent reported they had engaged in at least one type of academic misconduct during the surveyed year. ${ }^{106}$ Virginia Polytechnic Institute reported that various forms of academic cheating have more than tripled, from 80 in 1995/96 to 280 in $1997 / 98 .{ }^{107}$ Virginia Tech is one among numerous campuses that has seen a rise in plagiarized information stolen from the Internet, e-mail, and other digital communication services. ${ }^{108}$

Authors from Harvard University and the University of Illinois at UrbanaChampaign found that in their introductory political science course in the spring of 2000, about one out of eight papers seemed problematic. ${ }^{109}$ Another survey found that 54 percent of Penn students "considered copying homework to be 
cheating" and 61 percent would not "report a case of cheating to the Office of Student Conduct." ${ }^{\prime 10}$

In an article titled "Peer Trouble," John Crace claimed that the current system for ensuring the quality and integrity of research is not very failsafe. Reporting on a study by the University of Minnesota of four thousand researchers, he observed "that one in three scientists plagiarized, 22 percent handled data 'carelessly' and 15 percent occasionally withheld unfavorable data." ${ }^{111}$ In the scientific professional world, several recent incidents reported that stellar scholars at two highly regarded research institutions (Bell Labs, and separately at the Lawrence Berkeley National Lab) faked data. ${ }^{112}$

Anderson reported on numerous highly regarded journals that discuss instances of plagiarism among scientists and applied scientists. ${ }^{113}$ These are published in scholarly journals such as American Journal of Pharmacological Education, American Journal of Roentgenology, American Scientist, Nature, Science, Science News, and Scientific American. Other cases were reported in literature-related magazines, such as American Literature, English journal, Journal of Information Ethics, and Saturday Review of Literature. Popular magazines, including Business Week, Forbes, Harper's, The New Republic, and Wall Street Journal, also have cited cases of plagiarism on campuses and among various professions. Ronald B. Standler, an attorney at law, marshaled examples of statutes from fourteen states about sales of term papers and has presented detailed accounts of plagiarism by students, professors, and cases against commercial agencies that sell papers. ${ }^{114}$

Just how prevalent is cheating? The literature suggests some disturbing facts on the state of academic dishonesty in the United States. Questions the authors of this article wanted to learn next con- cerned prevention techniques, variables that might be used to predict this kind of behavior (age, gender, GPA, discipline, social and demographic factors), and pedagogical strategies based on the developmental and moral reasoning theory.

\section{What Is Done to Reduce Academic Dis- honesty in General?}

Several writers have offered prevention techniques to instructors against cyberplagiarists who know how to steal from the Web and online services. Michael Bugeja suggested the following prevention strategies: become an expert searcher, know your search engines, use a phrase from the first paragraph, choose odd or awkward phrases in text searches, among other tips. ${ }^{115}$ To this list, Kim McMurtry added academic honesty policy, giving specific instructions in assignments, awareness of paper mills, and plagiarism detection services. ${ }^{116}$

A comprehensive list of traditional sources of information need to be a requirement for all students. ${ }^{117}$ Lisa Renard distinguished among unintentional, sneaky, and lazy Internet cheaters and warned instructors to be aware of cheat sites, assign specific topics, tie in the assigned topics to student experiences, demand rewrites, and teach proper bibliographic attribution. ${ }^{118}$ Bear F. Braumoeller and Brian J. Gaines found that although verbal and written warnings not to plagiarize had a negligible effect on rates of plagiarism, plagiarism detection software, such as EVE and WordCHECK, proved to be successful in discouraging students from plagiarizing. ${ }^{119}$

An approach against plagiarism found in chapter 2 of Harris's Handbook is to teach students about plagiarism-related issues rather than assuming they know what plagiarism is. ${ }^{120}$ Using anecdotes, cartoons, and plain language, he demonstrated differences between plagiarism 
and copyright issues, between good citing practices and careless note-taking techniques, and among paraphrasing, summarizing, and copying sentences and paragraphs. An important section of his book is directed toward explaining reasons why plagiarism is unethical and the benefits of citing sources. In chapter 3 of his book, Harris discussed useful techniques that teachers can use to design assignments to reduce plagiarism. Other writers have shared their tips on how to cope with issues related to academic dishonesty. ${ }^{121-123}$

Pat G. Moeck examined the problem of cheating among community college students and has offered techniques for the detection and prevention of academic dishonesty, in general. ${ }^{124}$ Moeck offered a list of paper mills and another type of cyber-cheating prevention software. Other prevention techniques include discussing the issues in the classroom, allowing students to rewrite papers, and establishing campus honor codes. ${ }^{125,126}$ Based on responses obtained from 2,200 students on twenty-one college campuses, Donald L. McCabe and Linda Klebe Trevino concluded that schools with honor codes had fewer repeat offenders. ${ }^{127}$ This finding has policy implications, and honor codes have been widely practiced on numerous campuses. Other writings have emphasized the importance of feedback and distinguishing among different types of plagiarism. ${ }^{128-130}$ Scott Stebelman reminded us to rethink assignments, teach students that papers on the Web are not free of "legal and ethical intellectual property considerations," and refrain from posting student work on a course Web site. ${ }^{131}$

As more schools become wired and students more computer savvy, instructors are "complaining that new technologies have made it all too easy for students to gather the ideas of others and present them as their own." ${ }^{132}$ Jamie McKenzie wrote an article titled "The New Plagiarism: Seven Antidotes to Prevent Highway Robbery in the Electronic Age."133 Antidote \#1 distinguishes among levels and types of research, instructs educators to go beyond "just factual" scavenger hunts and to challenge students to use facts to explain, solve problems, and make decisions. Antidote \#2, "other people's ideas," "inspires plagiarism as the student gathers other people's ideas and then passes them off as her or his own." McKenzie offered practical suggestions on how to go beyond "conventional thinking." Other antidotes encourage students to "emphasize essential questions" (antidote \#3); "make their own answers" (antidote \#4); and learn how to paraphrase, summarize, and cite the sources of ideas or information (antidote \#5). Antidote \#6 suggests the use of color-coded text to differentiate between the ideas of others (black ink) and students' fresh ideas, reactions, or insights (green ink). Ercegovac used some of these techniques with seventh-grade students during information literacy (IL) units in note taking in English and History lessons. Finally, antidote \#7 deals with issues involved in self-evaluation techniques.

Sherri A. Whiteman and Jay L. Gordon, English teachers at Mount Lebanon Senior High School in Pittsburgh, have suggested that teachers need to be creative in their assignment topics, change assignments regularly, stay away from general and biographical-like essays, and "assign essays that can't be bought."134 Niels reported that the entire academic program at the Central Park East Secondary School (CPESS) in New York City is organized around the following main questions: Whose viewpoint is being described? What evidence is there? How is this connected to other things? What are the alternatives? How is this relevant? 
According to Niels, in order to deal with various forms of cheating behavior, we need to look at contextual factors that influence cheating, which is moral education. ${ }^{135}$ Kibler also felt that the moral climate of the institution impacts the rate of cheating. ${ }^{136}$

Verity J. Brown and Mark E. Howell studied the effectiveness of statements of plagiarism on students' behaviors. ${ }^{137}$ Their study concluded that there was a positive influence between students who read carefully worded statements and respective academic behaviors.

Many engineering and computer science departments have developed software that detects programming plagiarism. ${ }^{138,139}$ Some computer science students, although aware of such detection programs and harsh punishment actions, still copy codes. ${ }^{140}$ Rather than relying on tutorials for digital art assignments (e.g., Adobe's Illustrator), Michael Clayton and Adam Watkins have suggested focusing on concept mastery and customizing assignments. ${ }^{141}$

\section{Attitudes of Faculty toward Academic Dishonesty}

In his chapter titled "The Moral Atmosphere of the School," Lawrence Kohlberg summarized important findings by educational sociologists such as Emile Durkheim, Philip Jackson, Robert Dreeben, and Edgar Friedenberg. ${ }^{142} \mathrm{He}$ introduced the concept of "hidden curriculum," in which characteristics of the crowds, the praise, and the power (authority) are major influences on the development of children. In Coming of Age in America (1963), Friedenberg wrote: "After the family the school is the first social institution an individual must deal with, the place in which he learns to handle himself with strangers." ${ }^{143}$ Kohlberg's research built on that tradition and on the notions of Dewey and Piaget, and found that the development of moral reasoning is sequential progression through distinct stages. Kohlberg believes that the role of the teacher is to translate moral ideology into a working social atmosphere in which students understand the meaning of the "hidden curriculum" based on the universal principle of justice underlining respect for all people. In this context, teachers have considerable flexibility to implement "hidden curriculum" within respective school cultures.

Burke studied factors that influence faculty response to academic dishonesty at a multicampus, two-year college. His "research investigated faculty: 1) perceptions of the extent of academic honesty, 2) perceptions of, and attitudes toward, Academic Dishonesty Policy and policy implementation, 3) responses to academic dishonesty, 4) attitudes concerning values education, and 5) attitudes about responsibility for reducing academic dishonesty." ${ }^{\prime 14}$ His study delineated perceptions, responses, and attitudes among faculty grouped by employment status, campus, seniority, and discipline. A survey consisting of twenty-five questions was completed by 742 faculty members. The results indicated that faculty do not perceive academic dishonesty to be a serious problem. Further, faculty members believed themselves to be familiar with current policy and procedure and were unconcerned with policy implementation. The surveyed faculty members believed they have a primary role in values education. Of the faculty surveyed, 86 percent have suspected, and 65 percent have been certain of, academic dishonesty in their classrooms. Most of the surveyed members did not regularly follow institutional policy but, rather, handled incidents of cheating and plagiarism on an individual basis. They believed responsibility for reducing academic dishonesty lay primarily with students and individual faculty. The fact that 86 percent 
of the studied faculty suspected academic dishonesty in their classrooms but did not perceive it to be a major problem should be investigated further.

Studies by Peggy Jolly and by Alison Schneider support Burke's findings. ${ }^{145,146}$ Schneider reported that although college instructors complain about student cheating and plagiarism, many do little or nothing about it. Few file formal complaints against individual students and find the campus judicial process time-consuming and the penalties often unrelated to the offense. At institutions with honor codes, the issues can be different. In a report by Liora Pedhazur Schmelkin, Aviele M. Kaufman, and Dana E. Liebling, there was little or no agreement among surveyed faculty $(\mathrm{n}=160)$ as to what constitutes academic cheating. ${ }^{147}$ Marcoux's doctoral work studied college faculty's awareness level of the Kansas State University's honor code and cheating policies. ${ }^{148}$ Faculty responses varied and indicated that faculty members had not received training in how to handle cases of academic cheating.

Kay D. Johnston's article, although outside the authors' time line, is discussed here because it recounts a moral dilemma she dealt with relating to cheating that occurred during one of her unproctored exams. ${ }^{149}$ The incident involved some upper-division students in her Moral Development and Education course at Colgate University. She decided to use the incident as a teaching challenge and "role-taking" technique. The latter has been a fundamental concept that has guided much of inquiry and intervention in moral psychology and education. When Johnston confronted her students, she was alarmed at the range of their responses. Some were surprised if no one cheated, some did not know how to deal with cheating if it occurred, many rated cheating on a continuum, some viewed it as "refreshing the memory," and others were bothered that students majoring in education in that particular class cheated. The students were equally divided about moral decision making as a group. Johnston's analysis of cheating led her to search for causes of cheating behaviors beyond pressure and individual integrity. Believing that the notions of attachment and equality in the classroom are critical, she wrote: "it occurs because students do it if they won't 'get caught' and being caught by their peers is not problematic."150

It seems there is a lack of alignment between offences and punishment and a lack of communication among administrators, faculty, parents, and students. Other problems are related to students' state of readiness to understand issues involved in academic dishonesty and plagiarism and in relationships with peers, teachers, and as part of their educational climate as a whole.

\section{Can We Predict Academic Dishonesty?}

The reviewed literature identified specific variables that are positively associated with academic dishonesty behaviors. This type of research is important, but not dominant in the literature. This article first looks at recent studies that have examined the relationship in the context of the Internet. It then pays special attention to research pieces that empirically developed different phases of moral reasoning among different age groups. The section on further work describes work that might benefit from these studies as we continue to control, reduce, and educate the future generations of learners in ethical uses of information.

\section{Social Factors as Predictors of Academic Dishonesty}

In a broader context, the authors of this article sought to find societal indicators that strongly and positively correlate to 
academic dishonesty. Again, they turned to The State of Americans to find possible answers. ${ }^{151}$ The book marshaled evidence on changing youth behavior (chapter 1), economy and poverty (chapters 3 and 5), crime and punishment (chapter 4), the changing structure of American families (chapter 4), and American education (chapter 6). Over time, it seems that teenagers have become more skeptical in dealing with people and more disinterested in presidential elections and academic cheating has doubled. "Virtually every high school student in 1989 (97\%) admits having let another student copy from his or her work." 152 The trend of college students parallels that of secondary school students. Importantly, nuclear family correlates positively and strongly with students' academic performance (GPA scores), cheating behavior, drug use, and teenagers' trust of others.

Similarly, Ashworth and colleagues examined attitudes of nineteen colleges with regard to academic cheating and plagiarism in the U.K. ${ }^{153}$ They found that factors such as lack of trust, alienation from school, large classes, collaborative learning styles, and lack of understanding what plagiarism really meant were positively correlated with academic cheating and plagiarism.

In competitive classrooms across the board, under parent pressure to produce high grades, many students, including those from professional schools, have been found guilty of academic misconduct and plagiarism. ${ }^{154-157}$ This finding has been well documented with scores of studies about high school students by Niels. ${ }^{158}$ Kibler divided his literature review into "Personal Characteristics of Cheaters" and "Situational Factors Involved in a Student's Decision Whether to Cheat." Among the situational factors, important ones include unproctored tests, penalty systems, teaching styles (authori- tarian style incites cheating, overly difficult tests, hopelessness, soft teachers), climate of the school, and "likely to get caught." 159

Fred Schab wrote that high school graduates cheat because of "fear of failure" and because "parents demand and expect good grades" in order for their children to be admitted to top universities. Other reasons given were that everyone cheats and that teachers were "too soft on these issues."160 One writer at Whitney High School in Cerritos, California, reported that one student said that "a parent told him it was okay to cheat if he earned an A, because his future was at stake. Just don't get caught, he warned." ${ }^{161}$ Other students in the same school complained that cheating is rampant because they are given too many homework assignments. As a result, the students "share" the burden, copy from friends, and rely on paper mill services.

\section{Individual Differences as Predictors of Academic Dishonesty}

In the study mentioned earlier, Roberts, Anderson, and Yanish examined the relationship between demographic variables and academic dishonesty among undergraduates. ${ }^{162}$ A total of 422 students from twenty-two classes completed a 27-item self-reported survey that was designed to measure their involvement in seventeen types of academic misconduct. The survey also obtained data on class standing, age, gender, GPA, and college major. The results revealed that being male and/or younger than 24 years of age were characteristics associated with greater involvement in academic misconduct. "The greatest amount of collaboration was reported by Business students, while the least amount was reported by students in the Performing and Visual Arts. Conversely, Performing and Visual Arts majors reported the 
highest incidence of making up excuses to avoid handing in a term paper or taking a test on time." 163 The authors did not find a significant difference in self-reported academic misconduct between students and respective GPA scores.

Earlier studies on cheating among college students are discussed as a function of gender, academic status, age, GPA scores, and college major. ${ }^{164}$ The authors used a questionnaire to obtain data on self-reported frequency of twenty-one cheating behaviors $(n=943$ sophomores and juniors from nineteen disciplines). This "first large-scale study of cheating carried out in the United Kingdom" calculated the frequency with which each reason was given for both cheating and not cheating. ${ }^{165}$ Reasons given for cheating included time pressure, to get a higher grade, because everybody does it, to help a friend, and laziness. Students gave the following reasons for not cheating: "because it is immoral," "situation did not arise," "it was unnecessary," and "personal pride."166 The study found that cheating was more common among men, declines with age, and occurs more frequently among science and technology majors than among majors in other disciplines.

Alastair Pennycook wrote about some of the complexities of text, ownership, memorization, and plagiarism. ${ }^{167}$ The author suggested that plagiarism needs to be understood in terms of relationships among text, memory, learning, literacy, and cultural differences.

A total of 698 college students from nine universities completed a survey on Internet plagiarism. ${ }^{168} \mathrm{~A}$ substantial minority of the surveyed students reported that they used the Internet to copy and paste text into their own papers without giving credit to sources they used in their writings.

In an article titled "But I Wasn't Cheating: Plagiarism and Cross-cultural Mythology," Lise Buranen presented experiences with ESL (English as a Second Language) students and their writing problems and practices. ${ }^{169}$ In many cases, students lack a combination of vocabulary skills, factual knowledge, and bibliographic conventions. Accord-

\begin{tabular}{|c|c|c|}
\hline \multicolumn{3}{|c|}{$\begin{array}{c}\text { TABLE } 1 \\
\text { Kohlberg's Stages of Development in Moral Reasoning }\end{array}$} \\
\hline $\begin{array}{l}\text { Level I: } \\
\text { Preconventional morality } \\
\text { 1. Avoid punishment } \\
\text { 2. Personal gain }\end{array}$ & $\begin{array}{l}\text { 1. Rules are fixed that are obeyed } \\
\text { unquestionably: it is against the law to } \\
\text { steal, because you will be punished. } \\
\text { 2. Individualism and exchange: it is ok } \\
\text { to cheat,..., b/c reciprocal transaction } \\
\text { might be used. }\end{array}$ & $\begin{array}{l}\text { Age } 10 \\
\text { Grade } 5 / 6 \\
\text { elementary } \\
\text { school }\end{array}$ \\
\hline $\begin{array}{l}\text { Level II: } \\
\text { Conventional morality } \\
\text { 3. Good boy/nice girl } \\
\text { 4. Maintain law and order }\end{array}$ & $\begin{array}{l}\text { 3. Behaving in good ways: to steal } \\
\text { [medication, e.g.] is ok if this will help } \\
\text { a person get well (i.e., the wife may } \\
\text { heal). } \\
\text { 4. Concern with society as a whole. }\end{array}$ & $\begin{array}{l}\text { Age } 13 \text { middle } \\
\text { school } \\
\text { Age } 16 \text { high } \\
\text { school }\end{array}$ \\
\hline $\begin{array}{l}\text { Level III: } \\
\text { Postconventional morality } \\
\text { 5. Social contract } \\
\text { 6. Universal ethical prin- } \\
\text { ciples }\end{array}$ & $\begin{array}{l}\text { 5. People start to think about society } \\
\text { in a theoretical way, what is a good } \\
\text { society: democratic procedures for } \\
\text { changing unfair laws. } \\
\text { 6. Conception of justice requires us } \\
\text { to treat the claims of all parties in an } \\
\text { impartial manner. }\end{array}$ & $\begin{array}{l}\text { college students } \\
\text { adults in } 18+\end{array}$ \\
\hline
\end{tabular}




\begin{tabular}{|l|l|}
\hline \multicolumn{2}{|c|}{ TABLE 2 } \\
\hline \multicolumn{2}{|c|}{ Research Agenda: Studying Plagiarism in the Digital Age } \\
\hline \hline Educational Levels & Putting Research to Practice \\
\hline $\begin{array}{l}\text { Secondary school } \\
\text { students: Middle } \\
\text { school (grades 6-8); } \\
\text { student ages are } \\
\text { about 10-13. }\end{array}$ & $\begin{array}{l}\text { Contributions of Kohlberg on different phases of moral reason- } \\
\text { ing need to be mapped to pedagogical tools and strategies in the } \\
\text { context of information literacy (IL) standards, especially in the } \\
\text { context of cyber-plagiarism. Recommendation: Develop climate } \\
\text { based on trust, respect, and caring; pilot teaching units on academic } \\
\text { 9-12); ages are } \\
\text { about 14/15-18. } \\
\text { honesty to be practiced consistently across all classes; teach teach- } \\
\text { ers plagiarism prevention techniques; ensure that students are ready } \\
\text { for college-level learning. }\end{array}$ \\
$\begin{array}{l}\text { students; ages are } \\
\text { about 18 and up. }\end{array}$ & $\begin{array}{l}\text { Moral dilemmas should be developed for college level, representa- } \\
\text { tive of college majors, and integrated into IL projects. Recommen- } \\
\text { dation: Pilot and administer plagiarism pretest survey on content } \\
\text { knowledge, attitudes, and behaviors; design and deploy strategies } \\
\text { to cope with academic dishonesty, including plagiarism, consistent } \\
\text { with IL standards for 7-16 levels. }\end{array}$ \\
\hline $\begin{array}{l}\text { Graduate students } \\
\text { majoring in sci- } \\
\text { ences, social studies, } \\
\text { the humanities, and } \\
\text { professional schools. }\end{array}$ & $\begin{array}{l}\text { Allthough literature suggests that plagiarism drops with age, many } \\
\text { graduate students plagiarize. Recommendation: Problem-based } \\
\text { learning (PBL) and ethics should be mandatory. Model of evi- } \\
\text { dence-based medicine that is required in medical schools should be } \\
\text { further explored for other studies. }\end{array}$ \\
\hline
\end{tabular}

ing to Buranen, cultural differences also may influence student attitudes toward "borrowing" and "'ownership' of ideas or of text." 170 The notion of cultural perspective has been further explored by L. M. Dryden in the context of Japanese education. ${ }^{171}$ Angélil-Carter discussed developing writing skills in general and not limited to non-English language students. She wrote: "This is what is so difficult for the novice writer of academic discourse (or for any writer)-it is the control of the voices so that the authorial voice speaks through them." ${ }^{172}$ Nearly seventy years earlier, W. A. Edwards had written about "good and bad borrowing," differences between imaginative and unimaginative borrowing, and those between a derivative artist and a thief. ${ }^{173}$ He wrote: "many of them seem to be so craft-conscious in their writing, so full of reminiscences and echoes of other poets, and so thoroughly traditional in outlook and style, that the extremely Romantic critic must be puzzled by their apparent lack of originality."

Kohlberg empirically identified different stages of moral development and grouped them into the following three broad levels. ${ }^{174,175}$ (See table 1.) He used moral dilemmas to elicit subjects' beliefs and opinions at different stages of their development. Based on the children's reasoning, Kohlberg identified and classified reasoning into progressive stages of moral development.

\section{Further Work}

Research is needed to study predictors that might suggest students' behavioral patterns at different phases of their reasoning development. Attention also is needed in the areas of mapping research results to pedagogical units and specific disciplinary lesson plans, diagnostic and assessment tools that librarians, media specialists, and instructors could customize for their curricular needs. 
Table 2 suggests areas that are needed now in our IL programs across the educational ladder. In filling the cells below, we can provide a solid basis not only for college librarians and school media specialists, but also for school and university faculty, and policy makers.

\section{Notes}

1. John Dewey, Moral Principles in Education. Reprinted from the 1909 edition by permission of the Philosophical Library (New York: Greenwood Pr., 1969).

2. Jean Piaget, The Moral Judgment of the Child (New York: Simon \& Schuster, 1997).

3. - Science of Education and the Psychology of the Child (New York: Orion, 1970).

4. Lawrence Kohlberg, "Moral Stages and Moralization: The Cognitive-Developmental Approach," in Moral Development and Behavior: Theory, Research, and Social Issues, ed. T. Lickona (New York: Holt, Rinehart \& Winston, 1976).

5. ——, "The Moral Atmosphere of the School," pp. 149-63 in Readings in Moral Education, ed. Peter Scharf, with an introduction by Lawrence Kohlberg (Minneapolis, Minn.: Winston Pr., 1978).

6. Webster's College Dictionary (New York: Random House, 1991). 1989).

7. Oxford English Dictionary, 2nd ed., ed. J. Simpson and E. Weiner (Oxford: Clarendon Pr.,

8. West's Encyclopedia of American Law, 1998 ed. s.v. plagiarism.

9. Internet Encyclopedia of Philosophy. Available online at http://www.utm.edu/research/ iep $/ \mathrm{m} / \mathrm{m}$-dilemm.htm. [Accessed 17 April 2003].

10. Webster's College Dictionary, p. 1,032.

11. Oxford English Dictionary, p. 947.

12. Kohlberg, "Moral Stages and Moralization."

13. —_ "The Moral Atmosphere of the School."

14. Internet Encyclopedia of Philosophy.

15. Library of Congress Subject Headings, 21st ed. (Washington, D.C.: Library of Congress, Cataloging Distribution Service, 1998).

16. Sears List of Subject Headings, 17th ed., ed. Joseph Miller (New York: The H.W. Wilson Co., 2000).

17. Jonathan L. Burke, "Faculty Perceptions of and Attitudes toward Academic Dishonesty at a Two-year College" (Ph.D. diss., Athens, Ga., 1997).

18. Helene Elizabeth Marcoux, "Kansas State University Faculty Perspectives, Opinions, and Practices Concerning Undergraduate Student Academic Dishonesty and Moral Development (Ph.D. diss., Kansas State Univ., 2002).

19. Robert A Harris, The Plagiarism Handbook: Strategies for Preventing, Detecting, and Dealing with Plagiarism (Los Angeles: Pyrczak, 2001).

20. William L. Kibler, "Academic Dishonesty: A Student Development Dilemma," NASPA Journal 30 (summer 1993): 253.

21. Ibid.

22. Burke, "Faculty Perceptions of and Attitudes toward Dishonesty at a Two-year College."

23. Judy Anderson, Plagiarism, Copyright Violation, and Other Thefts of Intellectual Property: An Annotated Bibliography with a Lengthy Introduction (Jefferson, N.C.: McFarland, 1998).

24. Shelley Angélil-Carter, Stolen Language? Plagiarism in Writing (Harlow, Eng.: Pearson Education Limited, 2000).

25. Laurie Stearns, "Copy Wrong: Plagiarism, Process, Property, and the Law," pp. 5-17 in Perspectives on Plagiarism and Intellectual Property in a Postmodern World, ed. Lise Buranen and Alice M. Roy (New York: State Univ. of New York Pr., 1998).

26. K. R. St. Onge, The Melancholy Anatomy of Plagiarism (Lanham, Md.: Univ. Press of America, 1988).

27. Rebecca Moore Howard, Standing in the Shadow of Giants: Plagiarists, Authors, Collaborators, vol. 2 in Perspectives on Writing: Theory, Research, Practice (Stamford, Conn.: Ablex, 1999).

28. Earl Babbie, Plagiarism. Available online at http://www.csubak.edu/ssric/Modules/ Other/Plagiarism.htm. [Accessed 16 May 2003].

29. Patrick A. Cabe, "About Plagiarism" (from TIPSters). Available online at http://psych. skidmore.edu/plagiarism.htm. [Accessed 16 May 2003].

30. Council of Writing Program Administrators, "Defining and Avoiding Plagiarism: The WPA Statement on Best Practices." Available online at http://www.wpacouncil.org. [Accessed 16 May 2003].

31. Jan C. Swearingen, “Originality, Authenticity, Imitation, and Plagiarism: Augustine's Chinese Cousins," pp. 19-30 in Perspectives on Plagiarism and Intellectual Property in a Postmodern 
World, ed. Lise Buranen and Alice M. Roy (New York: State Univ. of New York Pr., 1998).

32. Jeffrey Klausman, "Teaching about Plagiarism in the Age of the Internet," Teaching English in the Two-year College 27 (Dec. 1999): 209-12.

33. Jane Lasarenko, “Teaching Paraphrase, Summary, and Plagiarism: An Integrated Approach," Exercise Exchange 41 (spring 1996): 10-12.

34. Ann Lathrop and Kathleen Foss, Student Cheating and Plagiarism in the Internet Era. A Wake-up Call (Englewood, Colo.: Libraries Unlimited, 2000).

35. Harris, The Plagiarism Handbook, 25.

36. Gary J. Niels, Academic Practices, School Culture and Cheating Behavior (Updated August 1, 2002). Unpublished report. Available online at http://winchesterthurston.org/files/cheating.pdf. [Accessed April 20, 2004]

37. Miguel Roig, "Can Undergraduate Students Determine Whether Text Has Been Plagiarized?' Psychological Record 47 (winter 1997): 113-23.

38. Association of College \& Research Libraries, Information Literacy Competency Standards for Higher Education (Chicago: ACRL, 2000).

39. American Library Association, Information Power: Building Partnerships for Learning (Chicago and London: ALA, 1998).

40. Burke, "Faculty Perceptions of and Attitudes toward Academic Dishonesty at a Twoyear College."

41. Kibler, "Academic Dishonesty."

42. Wilfried Decoo, Crisis on Campus: Confronting Academic Misconduct (Cambridge, Mass.: MIT Pr., 2002).

43. Dean R. Gerdeman, Academic Dishonesty and the Community College (2000). Report No. EDO-JC-00-07.

44. Eric Hoover, "Honor for Honor's Sake?" Chronicle of Higher Education 48 (May 2002): A34-A38.

45. Pat G. Moeck, "Academic Dishonesty: Cheating among Community College Students," Community College Journal of Research and Practice 26 (July 2002): 479-91.

46. Gail A. U. Overbey and Shawn F. Guiling, "Student Perceptions of Plagiarism and the Evaluation of Assignments," Journal on Excellence in College Teaching 10 (Mar. 1999): 3-22.

47. Tom Trinchera, "Cut and Paste Plagiarism: What It Is and What to Do about It," Community $\mathcal{E}$ Junior College Libraries 10 (Mar. 2001): 5-9.

48. Hoover, "Honor for Honor's Sake."

49. Carol Blaszczynski, "Conducting Ethical Business Education Research," Delta Pi Epsilon Journal 40 (fall 1998): 202-13.

50. Alex Aiken, A System, Developed at the University of California at Berkeley, for Detecting Software Plagiarism (MOSS: Measure of Software Similarity) of C, C++, Java, Pascal, Ada, ML, Lisp, or Scheme Programs in Programming Classes (1994). Available online at http://www.cs.berkeley. edu/ aiken/moss.html. [Accessed 15 May 2003].

51. John Crace, "Peer Trouble: How Failsafe Is Our Current System at Ensuring the Quality and Integrity of Research? Not Very," Guardian (Feb. 11, 2003). Available online at http://education. guardian.co.uk/Print/0,3858,4602456,00.html. [Accessed 15 May 2003].

52. Julie J. C. H. Ryan, "Student Plagiarism in an Online World," ASEE Prism Magazine (Dec. 1998). Available online at http://www.asee.org/prism/december/html/student_plagiarism_in_an_onlin.htm. [Accessed 17 April 2003].

53. Frank J. Collura, "Academic Corrective Action from a Legal Perspective," Journal of Dental Education 61 (Aug. 1997): 689-91.

54. Karen Cole Tankersley, “Academic Integrity from a Student's Perspective," Journal of Dental Education 61 (Aug. 1997): 692-93.

55. Klausman, "Teaching about Plagiarism in the Age of the Internet."

56. Lathrop and Foss, Student Cheating and Plagiarism in the Internet Era.

57. Michael Bugeja, "Busting the New Breed of Plagiarist," in Writer's Chronicle (Associated Writing Programs), The Association of Writers and Writing Programs, September 2000), 7 pages. Available online at www.awpwriter.org/magazine/writers/mbugeja.htm. [Accessed May 20, 2004]

58. Michael Clayton and Adam Watkins, "Assessment in the Digital Arts," Syllabus 15 (Apr. 2002): 31-34. Available online at http://www.syllabus.com/mag.asp?month=4\&year=2002. [Accessed 15 May 2003].

59. Gareth Denyer and Dale Hancock, "Graded Multiple Choice Questions: Rewarding Understanding and Preventing Plagiarism," Journal of Chemical Education 79 (Aug. 2002): 961-64.

60. Richard Drogemuller, "Designing Cyber-Assignments," Australian Science Teachers Journal 43 (Nov. 1997): 42-4.

61. Elizabeth Guiliano, "Deterring Plagiarism in the Age of the Internet," Inquiry 5 (spring 2000): 22-31. 
62. Michael Heberling, "Maintaining Academic Integrity in On-line Education," Online Journal of Distance Learning Administration 5 (spring 2002). Report No. EJ649248.

63. Jim Hu, "An Alternative Perspective of Language Re-use: Insights from Textual and Learning Theories and L2 Academic Writing," English Quarterly 33, no. 1-2 (2001): 52-62.

64. Fiona Hyland, "Dealing with Plagiarism When Giving Feedback," ELT Journal 55 (Oct. 2001): 375-81.

65. Lisa Renard, "Cut and Paste 101: Plagiarism and the Net," Educational Leadership 57 (Dec. 1999/Dec. 2000): 38-42.

66. Gregory L. Anderson, "Cyberplagiarism: A Look at the Web Term Paper Sites," College $\mathcal{E}$ Research Libraries News 60 (May 1999): 371-73.

67. Thomas Atkins and Gene Nelson, "Plagiarism and the Internet: Turning the Tables," English Journal 90 (Mar. 2001): 101-4.

68. Dan Carnevale, "Web Services Help Professors Detect Plagiarism," Chronicle of Higher Education 46 (Nov. 1999): A49.

69. JISC Technical Review of Free-text Plagiarism Detection Software (University of Luton, U.K.: Joint Information System Committee, no date). Available online at http://www.jisc.ac.uk/ uploaded_documents/luton.pdf [Accessed May 20, 2004.]

70. Kelly McCollum, "One Way to Get into College: Buy an Essay That Worked for Someone Else," Chronicle of Higher Education 43 (Feb. 1997): A25-A26.

71. Andrew Trotter, "Educators Turn to Anti-Plagiarism Web Programs to Detect Cheating," Education Week 20 (Dec. 2000): 14.

72. —— "Gotcha!: Anti-Plagiarism Web Programs Detect Cheating," Teacher Magazine 12 (Feb. 2001): 1.

73. Niels, Academic Practices, School Culture and Cheating Behavior.

74. Joanne Barrett, "Four Years of Portability: Perspectives on a Laptop Program," MultiMedia Schools 9 (Sept. 2002): 46-49.

75. Daniel D. Barron, “The Library Media Specialist, Information Power, and Social Responsibility: Part I (Plagiarism)," School Library Media Activities Monthly 18 (Feb. 2002): 48-51.

76. Darsie Bowden, "Coming to Terms: Plagiarism," English Journal, High School Edition 85 (Apr. 1996).

77. Laurel A. Clyde, “Electronic Plagiarism," Teacher Librarian 29 (Oct. 2001): 32, 58.

78. Gail Junion-Metz, "The E-plagiarism Plague," School Library Journal 46 (Sept. 2000): 43.

79. Rose D. McLaughlin and Steven M. Rose, "Student Cheating in High School: A Case of Moral Reasoning vs. Fuzzy Logic," High School Journal (Feb./Mar. 1989): 100.

80. Gary Putka, "A Cheating Epidemic at a Top High School Teaches Sad Lessons," Wall Street Journal, 29 June 1992, A1.

81. Joanne Troutner, "Plagiarism," Teacher Librarian 30 (Oct. 2000): 30-31.

82. Sherri A. Whiteman and Jay L. Gordon, "The Price of an 'A': An Educator's Responsibility to Academic Honesty," English Journal 91 (Nov. 2001): 25-30.

83. Burke, "Faculty Perceptions of and Attitudes toward Academic Dishonesty at a Twoyear College."

84. Peter Ashworth et al., "Guilty in Whose Eyes? University Students' Perceptions of Cheating and Plagiarism in Academic Work and Assessment," Studies in Higher Education 22 (June 1997): 187-203.

85. Urie Bronfenbrenner, Peter McClelland, Elaine Wethington, et al., The State of Americans: This Generation and the Next (New York: Free Press, 1996).

86. Sharon Myers, "Questioning Author(ity): ESL/EFL, Science, and Teaching about Plagiarism," TESL-EJ 3 (Mar. 1998). Available online at http://www-writing.berkeley.edu/RESL-EJ/ej10/a2.html. [Accessed 31 August 2003].

87. Stephen E. Newstead, Arlene Franklyn-Stokes, and Penny Armstead, "Individual Differences in Student Cheating," Journal of Educational Psychology 88, no. 2 (1996): 229-41.

88. Alastair Pennycook, "Borrowing Others' Words: Text, Ownership, Memory, and Plagiarism," TESOL Quarterly 30 (summer 1996): 201-30.

89. Fred Schab, "Schooling without Learning: Thirty Years of Cheating in High School," Adolescence 23 (winter 1991): 681-87.

90. Alison Schneider, "Why Professors Don't Do More to Stop Students Who Cheat," Chronicle of Higher Education 45 (Jan. 1999): A8-A10.

91. William L. Scurrah, "Plagiarism, Enclosure, and the Commons of the Mind." Paper presented at the 52nd Annual Meeting of the Conference on College Composition and Communication, Denver, March 14-17, 2001, ERIC Report No.: ED451 571. Available online at http://reading. indiana.edu.

92. Crace, "Peer Trouble."

93. Hoover, "Honor for Honor's Sake?" 
94. St. Onge, The Melancholy Anatomy of Plagiarism.

95. Francine Fialkoff, "Rampant Plagiarism," Library Journal 127 (Mar. 2002): 70.

96. Brian Hansen, “Combating Plagiarism," CQ Researcher 13 (Sept. 2003).

97. Patty Roberts, Janet Anderson, and Paula Yanish, "Academic Misconduct: Where Do We Start?" 27 p. Paper presented at the Annual Conference of the Northern Rocky Mountain Educational Research Association, Jackson, WY, October 1997. ERIC Report No.: ED415 780. Available at http://reading.indiana.edu.

98. Ian Zack, "The Latest Academic Vice: Computer-assisted Cheating," The New York Times, 16 September 1998. Available online at http://www.nytimes.com/library/tech/98/09/biztech/. [Accessed 15 May 2003].

99. Bronfenbrenner et al., The State of Americans.

100. Patrick M. Scanlon and David R. Neumann, "Internet Plagiarism among College Students," Journal of College Student Development 43 (May/June 2002): 374-85.

101. Kibler, "Academic Dishonesty."

102. Harris, The Plagiarism Handbook, v.

103. Ibid., vi.

104. Edward Humes, School of Dreams: Making the Grade at a Top American High School (Orlando, Fla.: Harcourt, 2003).

105. Niels, Academic Practices, School Culture and Cheating Behavior.

106. Roberts, Anderson, and Yanish, Academic Misconduct, 8.

107. Zack, "The Last Academic Vice."

108. Hoover, "Honor for Honor's Sake?"

109. Bear F. Braumoeller and Brian J. Gaines, "Actions Do Speak Louder Than Words: Deterring Plagiarism with the Use of Plagiarism-Detection Software," APSANET (The American Political Science Association Online) (Dec. 2001). Available online at http://www.apsanet.org/PS/ dec01/braumoeller.cfm?option=print. [Accessed 31 August 2003].

110. Mary Clarcke-Pearson, "Download. Steal. Copy. Cheating at the University," Daily Pennsylvanian, 27 November 2001. Available online at http://www.dailypennsylvanian.com/ vnews/display.v/ART/2001/. [Accessed 31 August 2003].

111. Crace, "Peer Trouble."

112. Charles Piller, "Prominent Physicist Fired for Faking Data Research: Bell Labs Says Scientist 'Recklessly' Misrepresented Work on Microprocessors," Los Angeles Times, 26 September 2002. Available online at:

http://www.latimes.com/news/science/la-sci-physicist26sep26.story.

[Accessed 31 August 2003]. 1

113. Anderson, Plagiarism, Copyright Violation, and Other Thefts of Intellectual Property.

114. Ronald B. Standler, Plagiarism in Colleges in USA (2000). Available online at http://www. rbs2.com/plag.htm. [Accessed 16 May 2003].

115. Bugeja, "Busting the New Breed of Plagiarist."

116. Kim McMurtry, "E-cheating: Combating a $21^{\text {st }}$ Century Challenge," T.H.E. Journal 29 (Nov. 2001): 36-38, 40-41.

117. Walter Minkel, "Web of Deceit-Libraries Must Play a Leading Role in Combating Online Plagiarism. Here's How," School Library Journal 48 (Nov. 2002): 50-53.

118. Renard, "Cut and Paste 101."

119. Braumoeller and Gains, "Actions Do Speak Louder Than Words."

120. Harris, The Plagiarism Handbook.

121. Susannah Feldman, Virginia Anderson, and Luz Mangurian, "Teaching Effective Scientific Writing: Refining Students' Writing Skills within the Towson Transition Course," Journal of College Science Teaching 30 (May 2001): 446-49.

122. Joshua D. Landau, Perri B. Druen, and Jennifer A. Arcuri, "Methods for Helping Students Avoid Plagiarism," Teaching of Psychology 29 (spring 2002): 112-15.

123. Kelley A. Lawton and Laura Cousineau, "Plagiarism: Its Nature and Consequences. From The University Writing Program, Guide to Library Research" (Duke University Libraries, August 29, 2001). Available online at http://www.lib.duke.edu/libguide/plagiarism.htm. [Accessed 16 May 2003].

124. Moeck, "Academic Dishonesty."

125. Guiliano, "Deterring Plagiarism in the Age of the Internet."

126. Heberling, "Maintaining Academic Integrity in On-line Education."

127. Donald L. McCabe and Linda Klebe Trevino, "Honesty and Honor Codes," Academe 88 (Jan./Feb. 2002): 37+.

128. Klausman, "Teaching about Plagiarism in the Age of the Internet."

129. Roig, "Can Undergraduate Students Determine Whether Text Has Been Plagiarized?"

130. Hyland, "Dealing with Plagiarism When Giving Feedback." 
131. Scott Stebelman, "Cybercheating: Dishonesty Goes Digital: Web Makes Plagiarism Easier But Offers Librarians New Methods of Detection," American Libraries 29 (Sept. 1998): 48-50.

132. Jamie McKenzie, "The New Plagiarism: Seven Antidotes to Prevent Highway Robbery in the Electronic Age," Educational Technology Journal 7 (May 1998). Available online at http://www. fno.org/may98/cov98may.html. [Accessed 17 April 2003].

133. Ibid.

134. Whiteman and Gordon, "The Price of an 'A.'”

135. Niels, Academic Practices, School Culture and Cheating Behavior.

136. Kibler, "Academic Dishonesty."

137. Verity J. Brown and Mark E. Howell, "The Efficacy of Policy Statements on Plagiarism:

Do They Change Views," Research in Higher Education 42, no. 1 (2001): 103-18.

138. Aiken, A System, Developed at the University of California at Berkeley, for Detecting Software Plagiarism.

139. Gareth Denyer and Dale Hancock, "Graded Multiple Choice Questions: Rewarding Understanding and Preventing Plagiarism," Journal of Chemical Education 79 (Aug. 2002): 961-64. Report No. EJ651216.

140. Zack, "The Latest Academic Vice."

141. Clayton and Watkins, "Assessment in the Digital Arts."

142. Kohlberg, "The Moral Atmosphere of the School."

143. Quoted in Kohlberg, "The Moral Atmosphere of the School," 149.

144. Burke, "Faculty Perceptions of and Attitudes toward Academic Dishonesty at a Twoyear College," 3.

145. Peggy Jolly, The Ethics of Plagiarism (Alabama: 1998). Report No. 1998-04-00.

146. Schneider, "Why Professors Don't Do More to Stop Students Who Cheat."

147. Liora Pedhazur Schmelkin, Aviele M. Kaufman, and Dana E. Liebling, Faculty Assessments of the Clarity and Prevalence of Academic Dishonesty (2001).

148. Marcoux, "Kansas State University Faculty Perspectives, Opinions, and Practices."

149. Kay D. Johnston, "Cheating: Reflections on a Moral Dilemma," Journal of Moral Education 20, no. 3 (1991): 283-91.

150. Ibid., 290.

151. Bronfenbrenner et al., The State of Americans.

152. Ibid., 4 .

153. Ashworth et al., "Guilty in Whose Eyes?"

154. Crace, "Peer Trouble."

155. Collura, "Academic Corrective Action from a Legal Perspective."

156. Patrick G. Love and Janice M. Simmons, "The Meaning and Mediated Nature of Cheating and Plagiarism among Graduate Students in a College of Education" (paper presented at the Annual Meeting of the Association for the Study of Higher Education, 1997).

157. Myers, "Questioning Author(ity)."

158. Niels, Academic Practices, School Culture and Cheating Behavior.

159. Kibler, "Academic Dishonesty," 257-59.

160. Schab, "Schooling without Learning," 840.

161. Humes, School of Dreams, 104.

162. Roberts, Anderson, and Yanish, Academic Misconduct.

163. Ibid., 10 .

164. Newstead, Franklyn-Stokes, and Armstead, "Individual Differences in Student Cheating."

165. Ibid., 238.

166. Ibid., 233.

167. Pennycook, "Borrowing Others' Words."

168. Scanlon and Neumann, "Internet Plagiarism among College Students."

169. Lise Buranen, "'But I Wasn't Cheating': Plagiarism and Cross-cultural Mythology," pp. 63-74 in Perspectives on Plagiarism and Intellectual Property in a Postmodern World, ed. Lise Buranen and Alice M. Roy (Albany, N.Y.: State Univ. of New York Pr., 1999).

170. Ibid., 66.

171. L. M. Dryden, "A Distant Mirror or through the Looking Glass? Plagiarism and Intellectual Property in Japanese Education," pp. 75-85 in Perspectives on Plagiarism and Intellectual Property in a Postmodern World, ed. Lise Buranen and Alice M. Roy (Albany, N.Y.: State Univ. of New York Pr., 1999).

172. Angélil-Carter, Stolen Language, 35.

173. W. A. Edwards, Plagiarism: An Essay on Good and Bad Borrowing (Cambridge, Eng.: Gordon Fraser, Minority Press, 1933).

174. Kohlberg, "Moral Stages and Moralization."

175. _— "The Moral Atmosphere of the School." 